\title{
Review
}

\section{Targeting gene therapy vectors to CNS malignancies}

\author{
Matthew A Spear ${ }^{1,2}$, Ulrich Herrlinger ${ }^{1}$, Nikolai Rainov ${ }^{1}$, Peter Pechan $^{1}$, Ralph Weissleder ${ }^{3}$ and \\ Xandra O Breakefield ${ }^{1}$ \\ ${ }^{1}$ Department of Neurology, Molecular Neurogenetics Unit, ${ }^{2}$ Department of Radiation Oncology, ${ }^{3}$ Department of \\ Diagnostic Radiology, Massachusetts General Hospital \& Harvard Medical School, Bldg 149, 13th St., Charlestown, \\ Massachusetts 02129, USA
}

\begin{abstract}
Gene therapy offers significant advantages to the field of oncology with the addition of specifically and uniquely engineered mechanisms of halting malignant proliferation through cytotoxicity or reproductive arrest. To confer a true benefit to the therapeutic ratio (the relative toxicity to tumor compared to normal tissue) a vector or the transgene it carries must selectively affect or access tumor cells. Beyond the selective toxicities of many transgene products, which frequently parallel that of contemporary chemotherapeutic agents, lies the potential utility of targeting the vector. This review presents an overview of current and potential methods for designing vectors targeted to CNS malignancies through selective delivery, cell entry, transport or transcriptional regulation. The topic of delivery encompasses physical and pharmaceutic means of increasing the relative exposure of tumors to vector. Cell entry based methodologies are founded on increasing relative uptake of vector through the chemical or recombinant addition of ligand and antibody domains which selectively bind receptors expressed on target cells. Targeted transport involves the potential for using cells to selectively carry vectors or transgenes into tumors. Finally, promoter and enhancer systems are discussed which have potential for selectivity activating transcription to produce targeted transgene expression or vector propagation.
\end{abstract}

Keywords: CNS malignancies; brain tumor; vector; targeting; gene therapy; glioma; glioblastoma

\section{Introduction}

Therapy for CNS malignancies, in particular intracranial malignant gliomas, currently relies on the three modalities surgery, radiation and chemotherapy. With modern treatment paradigms the median survival time of patients with the most malignant glioma, glioblastoma multiforme (GBM), has increased from several months to over a year in selected series (Walker et al, 1978; Kristiansen et al, 1981; Gutin et al, 1991). Survival in patients with other intracranial primary neoplasms and metastatic disease has likewise increased. Although several of these diseases now have significant cure rates, the majority are eventually lethal in a large proportion of patients. Each therapeutic modality has its own mechanism and profile of selective elimination of tumor cells as opposed to normal cells, and thus provides a unique contribution to the therapeutic

Correspondence: MA Spear, MD

Received 10 June 1997; accepted 25 June 1997 ratio. To a large degree, therapies are combined such that additive or synergistic toxicity to tumor cells is maximized, while toxicity to normal tissue is minimized. Clinical tumor burdens may consist of $10^{9}-10^{12}$ cells, of which a therapeutic regimen must eliminate all competent clonogens to result in a cure. This goal is frequently not achieved because each modality first reaches a point at which its toxicity to vital normal tissue is limiting and overlaps with other existing agents.

Over the past 10 years a number of synthetic and viral vectors have been developed to deliver transgenes which have potential therapeutic applications in treating malignancies of the CNS. The advantage of gene therapy lies in the potential for additional, precisely designed, selective toxicity for tumor cells. In conjunction with current therapies, gene therapy may allow for selective elimination of remaining tumor cells, resulting in prolongation of survival or cure. The source of selectivity can range from preferential toxicity of the transgene product 
to targeting of vector activity to the tumor or affected tissue. The principal focus of this review, vector targeting, can be accomplished by several means including selective vector delivery, cell entry (receptor targeting), intracellular transport or transcriptional activation (promoter targeting). Although high grade gliomas are referenced primarily in this article, many of the techniques are applicable to a broad range of malignancies in the CNS and other sites.

\section{Targeted delivery}

The most direct means of targeting a therapeutic agent is through the means and location of delivery. A straightforward method is surgical placement into the tumor mass or resection cavity. Because the two most common adult intracranial malignancies, exogenous metastases and gliomas, frequently involve the brain in a diffuse and microscopic manner, intrathecal and intravascular administration have been investigated as more pervasive means of delivery. Intravascular delivery is affected by the unique characteristics of the normal CNS vasculature and tumor neovasculature. The former composes the relatively impermeable blood brain barrier (BBB), the latter is more permeable but associated with unusual fluid dynamics, and both react differentially to various manipulations. Attempts have been made to exploit these differential characteristics through vector design and pharmacologic manipulation.

Initial protocols with most vectors have employed stereotactic intratumoral injection of virus or virus-producing (packaging) cells (Chiocca et al, 1994; Oldfield et al, 1993; Kramm et al, 1995). This can provide relatively efficient gene delivery to focal regions in circumscribed solitary tumors, but does not address local invasion, distant migration or diffuse seeding by tumor cells (Berens et al, 1990). Intrathecal delivery of vectors or packaging cells is a technique that provides more extensive exposure for tumor foci growing in or around CSF spaces, and can facilitate transduction of a higher percentage of tumor cells under such conditions (Kramm et al, 1996; Culver et al, 1992). Using an HSV-derived vector, which propagates on site in dividing tumor cells, this method has produced an even distribution of transgene delivery to tumor throughout the CSF and within the brain tissue adjacent to the ventricular space (Kramm et al, 1996).

Since almost all viable tissue requires vascular support, intravascular administration appears to present the greatest potential for delivering a vector to the largest proportion of tissue at risk for involvement by a diffuse or multifocal tumor. Retroviral vector administered through the portal vein has already been shown to preferentially transduce tumor deposits compared to normal liver
(Hurford et al, 1995). This effect may result from the intrinsically high permeability of tumor induced neovasculature, mechanical disruption of vascular integrity by tumor or the higher mitotic rate of tumor cells. Albeit dependent on tumor location and individual vascular anatomy, intracarotid administration is expected to provide more intracranial lesions with the highest relative exposure to vector.

The existence of a tight blood-brain-barrier (BBB) throughout the normal brain provides an additional advantage in terms of vector selectivity for CNS neoplasms. The varying permeability found throughout the blood-tumor-barrier (BTB) in the majority of brain tumors (Bergstrom et al, 1983), however, may restrict maximal penetration by vector. The BTB can be further manipulated to increase permeability to small particles such as viruses. Several studies have focused on transient osmotic disruption of tight junctions between endothelial cells, and this technique has been well characterized in animal models and in humans as an enhancer of chemotherapeutic drug and vector delivery to brain tumors (Doran et al, 1995; Neuwelt and Hill, 1987; E4">, 1995). With mannitol disruption of the BBB, however, delivery and uptake of therapeutic agents is less specific to the tumor and there can be toxic side effects (Zunkeller et al, 1996).

Recently, it has been demonstrated that BTB disruption by low-dose bradykinin (BK) can facilitate selective uptake of intra-arterially administered HSV vectors to single or multiple tumor foci in the rodent brain, with essentially no infection of normal neurons and glia (Rainov et al, 1995. BK, a nonapeptide hormone that interacts with specific B1 and B2 receptors on endothelial cells opening tight junctions and enhancing endocytosis (Elliot et al, 1996; Bartus et al, 1996), selectively increases the permeability of tumor capillaries when infused intra-arterially at low doses (Inamura et al, 1994). Rainov et al (1995) demonstrated that transgene expression after intra-arterial BK infusion and HSV1 vector administration is particularly intense in the periphery of the tumor, a zone with distinct biological and biomechanical properties such as high mitotic rates, angiogenesis, parenchymal invasion and low interstitial pressure (Boucher et al, 1996). Up to $25 \%$ of tumor cells in this region express transgene proteins after BK/HSV-1 administration, as compared to less than $0.1 \%$ of cells in normal brain tissue (Rainov et al, 1995). In an attempt to replace BK with a new long-acting derivative, the synthetic octapeptide RMP-7 (Alkermes Inc.), which is approved for human studies and acts more selectively on endothelial cells (Elliot et al, 1996), is currently being tested. Initial studies have shown it to be equivalent to BK in selectively increasing HSV-1 transduction (Barnett et al, manuscript in preparation). 


\section{Receptor targeting}

Most viruses, which most vectors are or resemble, use viral surface proteins that bind to specific cell surface molecules (receptors) as the primary means of initiating cellular attachment. Expression of the receptors on a single or limited range of cell types produces the tissue tropism seen with many viruses. This effect is frequently a major determinant in the disease syndrome produced. A separate domain of the binding protein, an associated protein or a completely unrelated protein usually provides a subsequent and usually less specific membrane fusion or penetration function. Many of the commonly used viral vectors actually infect a relatively broad spectrum of host cells, and the nonviral vectors have almost no intrinsic selectivity. Since the therapeutic target in a gene therapy strategy is frequently a single cell type or subset, particularly in an oncologic setting, significant interest exists in increasing specificity of infectivity by adding or altering receptor binding moieties. This has been attempted by attaching or conjugating various receptor ligands and specific antibodies, as well as by recombinant modification of viral surface molecules with binding domains from ligands or antibodies. Adding surface conjugates or altering viral surface proteins may also serve to obscure native binding functions and truncate the vector's ability to effect endogenous, unwanted tissue tropisms or non-specific infectivity.

A number of nonviral vectors have been targeted by introducing specific ligands into DNA-polylysine complexes. Folate (Gottschalk et al, 1994), epidermal growth factor (EGF) (Cristiano et al, 1996) and transferrin (Wagner et al, 1992) have been used to target tumor cells or specific tissues which overexpress the corresponding receptor. Alternatively, streptavidin has been incorporated into the complexes, allowing the attachment of varying biotinylated ligands and antibodies (Schwarzenberger et al, 1996). Defective or inactivated adenovirus is frequently included as an endosomal lysis agent, thereby increasing transfection efficiency (Gao et al, 1993). Targeting ligands and antibodies have also been added to liposomes. Transferrin, for example, has been solubilized into liposomes and shown to target them to tumor cells which overexpress transferrin receptor (TfR)
(Cheng, 1996). Antibodies against TfR (Huwyler et al, 1996) and the polyoma-virus-induced tumor associated antigen (Emanuel et al, 1996) have also been used to effectively target vectors. Specific spatial targeting of viral or non-viral vectors could also be accomplished through conjugation or adsorption of ferrofluids (biocompatible iron-oxide compounds), which have previously demonstrated efficacy in targeting pharmaceuticals using magnetic fields (Lubbe et al, 1996).

With current recombinant technology, the logical extension of this strategy is to alter the peptide sequences of the viral surface proteins themselves. The Moloney murine leukemia virus (MMLV) gp70 envelope protein, which mediates binding to ubiquitously expressed amino acid transport proteins (Albritton et al, 1995), has been modified in a variety of ways and expressed in trans in packaging cell lines (pseudotyping). Kasahara et al, inserted the receptor-binding domain of erythropoietin and achieved increased transduction of erythropoietin receptor-bearing human cells, including erythroid and erythroleukemia cell lines, and decreased transduction of cell lines not expressing erythropoietin receptors (Kasahara et al, 1994). A range of tumor selective ligand epitopes have been utilized in similar systems (Table 1). Modifications have also been introduced into the fiber protein of adenovirus. For example, Michael et al, have inserted a binding epitope from gastrin releasing peptide (Michael et al, 1995). Wickham et al, inserted a FLAG peptide then used bispecific anti-FLAG/ anti- $\alpha_{\mathrm{v}}$ integrin monoclonal antibodies (MAb) to target human venule endothelial cells and intestinal smooth muscle cells bearing $\alpha_{\mathrm{v}}$ integrin (Wickham et al, 1996).

An important derivation of this strategy has been the recombinant insertion of specific antibody binding domains, with the heavy and light chain variable regions combined in a single chain fragment variable $\left(\mathrm{scFv}_{\mathrm{v}}\right)$, into viral surface proteins. Germinal work was done by Russel et al, placing an scFv against 4-hydroxy-5-iodo-3-nitrophenacetyl capronate (NIP) (Russel et al, 1995) into the MMLV gp70 envelope protein. Antibody fusion proteins have subsequently been created to target MMLV to cells bearing MHC class I (Marin et al, 1996) and LDL receptors (Somia et al, 1995), and spleen

Table 1 Tumor targeting ligands recombined into retrovirus envelope

\begin{tabular}{lll}
\hline Ligand & Targeted tumor type (receptor) & Reference \\
\hline $\begin{array}{l}\text { Erythropoietin } \\
\text { Epidermal growth factor (EGF) }\end{array}$ & Erythroleukemia (EPO-R) & Kasahara et al, 1994 \\
Heregulin & Epithelial malignancies (EGFR) & Cosset et al, 1995 \\
Schnierle et al, 1996b & Han et al, 1995 \\
$\begin{array}{l}\text { Neurotensin } \\
\text { Urokinase-type plasminogen activator }\end{array}$ & Creast (ErbB) & Schnierle and Groner, 1996a \\
\hline
\end{tabular}


necrosis virus (SNV) to cells bearing the hapten DNP (Chu et al, 1994). Caution must be exercised with such methodologies in that recombinant viral proteins are frequently improperly processed and packaged, resulting in functionally inactive forms (Gray and Roth, 1993; Schnierle et al, 1996b).

A number of protein moieties have been characterized that may have particular potential in targeting vectors specifically to the CNS or CNS malignancies via ligand-receptor interactions. The malignancy-associated extracellular matrix protein, tenascin, for which $\alpha_{8} \beta_{1}$ integrin is a receptor, is expressed by a large proportion of glioblastomas (Ventimiglia et al, 1992; Higuchi et al, 1993). MAb to tenascin have been administered stereotactically and intravascularly as ${ }^{131}$ I-immunoradiotherapeutic conjugates, which localized to tumors at ratios ranging up to 200:1 compared to normal brain, and resulted in prolonged survival in rat models and radiographic responses in humans (Zalutsky et al, 1989; Lee et al, 1988; Bigner et al, 1995). Vitronectin, a matrix adhesion protein whose receptors include $\alpha_{\mathrm{v}} \beta_{3}$ and $\alpha_{\mathrm{v}} \beta_{5}$ integrins, is preferentialy expressed by astrocytomas where they actively invade brain parenchyma, and levels of expression correlate with degree of malignancy (Gladson et al, 1991, 1995). Brain-enriched hyaluronan-binding protein (BEHAB) is another gliomaassociated matrix protein which has recently been characterized by Jaworski and Hockfield (1996). Expressed transiently during embryonic gliagenesis and migration, BEHAB is absent in the adult brain except in glia-derived tumors, in which levels of expression correlate with the capacity for parenchymal infiltration.

When considering receptor targeting for treating CNS malignancies, questions arise as to which anatomic structures other than the tumor, such as the tumor neovasculature, brain parenchyma or CNS vascular endothelium, should be primarily targeted. The diffuse nature of many CNS neoplasms and the existence of non-neovascularized microscopic tumor deposits suggests that widespread delivery to the latter two structures might be advantageous for vectors selectively toxic to neoplastic cells. The vascular endothelium of tumor or brain may provide a functional, pervasive and accessible target. A non-cytocidal replication-competent vector could primarily infect endothelium then delivery progeny to the parenchyma behind. Replicationconditional vectors that selectively propagate in and kill mitotic cells, may do the same in rapidly proliferating neovascular endothelium and tumor. Yuan et al, have also shown that liposomes of $400 \mathrm{~nm}$ in diameter can cross gaps in neovascular endothelium (Yuan et al, 1995). The largest of the currently used viral vectors, HSV-1, is $180 \mathrm{~nm}$ in diameter and, as discussed above, has been shown to cross into tumors. Thus vector passing through the blood stream could be retained by vascular endothelial receptors and diffuse across into the tumor, or even have direct exposure to receptors expressed on tumor cells themselves. Although viral vectors can access the tumor parenchyma from the vascular space, the hematologic and interstitial flow and pressure dynamics of tumors may variably curtail vector diffusion (Netti et al, 1995). Endothelial cells are also known to transcytose the ligands for specified receptors, including transferrin (Fishman et al, 1987), insulin (Ben-Shacher et al, 1988) and low-density lipoprotein (Urien et al, 1987), across the BBB, and this function has already been utilized for transport of pharmaceuticals (Frieden, 1993a). For vectors targeted to such receptors, however, there is a risk of fusion with and primary transduction of the endothelial cells, rather than passage across them. Such apparent barriers may actually not abrogate therapeutic efficacy. In addition to providing a potential source of progeny vector to tumor cells, transduction of tumor vascular endothelium that results in endothelial cell toxicity would be expected to have some therapeutic effect though vascular deprivation of the tumor, as protocols with a number of anti-neovasculature agents, such as angiogenesis inhibitors, have indicated (Yanase et al, 1993). The phenotypic similarities of neovasculature among different tumor histologies may provide additional advantages in extending the spectrum of tumors targeted by a single vector. Vascular endothelial growth factor receptors (VEGFR) present a potential target given their relatively selective expression on tumor neovasculature and critical role in angioneogenesis (Plate et al, 1994; Hatva et al, 1995). Transferrin receptors (TfR) present another useful target, since they are preferentially expressed on brain and probably neovascular capillary endothelium (Jefferies et al, 1984; Dore-Duffy et al, 1994), as well as on a number of tumors originating in the CNS, including medulloblastomas, neuroblastomas and glioblastomas (Jefferies et al, 1984; Martell et al, 1993). TfR can be targeted using either transferrin or anti-TfR monoclonal antibodies. The latter appear preferable due to lack of competitive inhibition of binding by normally high levels of endogenous circulating transferrin. Various pharmaceuticals have been targeted to the CNS and tumors using anti-TfR antibody conjugates (Ito et al, 1991; Frieden et al, 1991, 1993b). Toxin conjugates have eradicated glioma implants in animal models when given through intravascular or intratumoral routes (Laske et al, 1994; Ito et al, 1991). Recent reports have documented increased transfection of HeLa cells by adding transferrin to liposomes (Cheng, 1996) and increased delivery of daunomycin to the brain in rats using 
liposomes conjugated to the Ox26 anti-TfR Mab (Huwyler et al, 1996). We have conjugated Ox26 to an HSV-1 vector and demonstrated increased transduction of lacZ into TfR-upregulated myoblast and gliosarcoma cell lines (Spear et al, 1997).

Phage display may provide an additional source of recombinant peptide sequences for targeting. The technique initially utilized for isolating small peptides of specified affinity by Parmley and Smith (1989) and Ladner and Guterman (1990) in the early 1990s. Nearly random oligonucleotide sequences are inserted into the filament binding protein of an E. coli filamentous phage (frequently protein III of the M13 phage) to generate a library of phage expressing approximately $10^{7}-10^{9}$ different peptides. Phage expressing a peptide sequence having high affinity for a specific molecule or tissue can then be selected out for expansion by in vitro binding and elution (Scott and Smith, 1990) or in vivo hematogenous administration and organ specific recovery (Pasqualini and Ruoslahti, 1996). The DNA sequences coding for the binding peptides are subsequently recovered from the phage genome. Peptides that target a number of molecules and tissues, including the brain, have been reported (O’Neil et al, 1995; Pasqualini and Ruoslahti, 1996).

\section{Targeted cellular transport (carrier cells)}

Viral vectors are typically generated in culture using packaging cells (retrovirus) or permissive cells (HSV and adenovirus). Depending on the type of vector, the viral genome may be introduced into these cells in intact or in segments. Progeny virus is produced and released either with or without cytopathic effect on the host cell, again depending on the specific vector and system. The fact that translated viral products derived from physically separate DNA sequences placed in the same host cell in trans can be incorporated into the same progeny virion, has been used to express many of the recombinant binding proteins discussed above. Packaging cells producing retroviral vectors have previously been placed into the brain stereotactically (Chiocca et al, 1994; Oldfield et al, 1993 rep Short et al, 1990). Although most commonly used vector producing cells have little or no migratory potential or specific tropisms, other cell types with these properties could be used to transport vector production to and within CNS tumors in a targeted manner.

Lymphocytes comprise one of the most promosing cell populations for carrier-mediated delivery. Lymphocytes circulate throughout the vascular system and infiltrate tissues, and selected lymphocyte populations appear to home to tumors and the CNS. In vitro-sensitized (IVS) lymphoid cells and lymphokine-activated killer (LAK) cells have been isolated from the peripheral hematolymphoid system and expanded in culture using IL-2, with or without tumor cell co-culture. When infused intravenously, IVS and LAK cells have been reported to attack and eliminate pulmonary and hepatic micrometastases in murine models (Mule et al, 1984; Papa et al, 1986; Lafreniere and Rosenberg, 1985; Shu et al, 1987), as well as metastatic tumors in a variety of sites in humans (Schoof et al, 1988; Negrier et al, 1989). Tumor infiltrating lymphocytes (TIL), isolated from melanoma, renal cell carcinoma, lung carcinoma, breast carcinoma, colon carcinoma and other malignancies, can home to, infiltrate and elicit complete responses in metastatic tumor deposits when injected intravenously (Itoh et al, 1986; Kurnick et al, 1986; Rabinowich et al, 1987; Miescher et al, 1987). Specifically, ${ }^{111} \mathrm{In}-$ labeled TIL uptake in extra-cranial tumors 3-40 times higher than normal tissue has been seen, with up to $4.5 \times 10^{7}$ TIL estimated to infiltrate each gram of tumor (Fisher et al, 1989; Griffith et al, 1989). The ability of TIL to selectively home, however, has recently been questioned by one study that failed to show selective tumor uptake of NeoR marked TIL (Nerrouche et al, 1995). Further, the CNS presents a potentially more complicated target given its supposed, albeit disputed, status of immune privilege (Weller et al, 1995, 1996). Although trials using locally administered LAK to treat gliomas have indeed not demonstrated therapeutic efficacy (Weller et al, 1995), a cytotoxic T-Cell response, as well as functional LAK and TIL have been observed in a significant proportion of gliomas (Paine et al, 1986; Kuppner et al, 1988; Yoshida et al, 1989). Trafficking of systemically administered TIL to gliomas, albeit of low efficiency, has also been reported in murine tumor models (Saris et al, 1992). Recent reports from Inoue et al, have demonstrated infiltration and elimination of murine intracranial fibrosarcoma implants by a subset of intravenouslyadministered, bacterial superantigen-activated $\mathrm{T}$ cells (Inoue et al, 1996). Specific T cell populations have also been characterized that home to and infiltrate the CNS and PNS (peripheral nervous system) in experimental allergic encephalomyelitis (EAE) (Linington et al, 1993) and experimental allergic neuritis (EAN) (Kramer et al, 1995) animal models, respectively.

TIL have already been successfully used to transport transgenes to tumors. Initial studies demonstrated infiltration of tumors with TIL which had been transduced ex vivo with the NeoR marker gene using a MMLV retroviral vector (Rosenberg et al, 1990). MMLV-transduced TIL have further been used to transport tumor necrosis factor alpha (TNFa) expression into tumors with therapeutic intent (Hwu et al, 1993, 1997). T cells have also been transduced in vitro and used to deliver nerve growth factor (NGF) production to the peripheral nervous system in the aforementioned EAN model 
(Kramer et al, 1995). The problem still remains that many viruses, including adenovirus and HSV, can be rapidly cytotoxic to their host cells. Also, a hematogenously disseminated carrier cell that constituitively produces vector will result in nonspecific systemic exposure to vector until it is sequestered in its target tissue. Constituitive expression of viral antigens may also result in immune mediated elimination of the carrier cell.

Several of these obstacles could be circumvented by stereotactically implanting cells that would migrate away from the primary tumor site, ideally following the paths of infiltrating malignant cells. Several non-malignant, migratory cells lines have been described. Rat endothelial cells, immortalized by transfection with E1A, have been shown to migrate across subcutaneous glioma implants and incorporate into the tumor neovasculature (Lal et al, 1994). The murine neural progenitor cell line, C172 , is highly migratory in the CNS (Snyder et al, 1992) and appears to distribute throughout experimental tumors in the rat brain (Aboody-Guterman et al, 1996).

Further potential exists for engineering lymphocyte or non-lymphocyte cell surface receptors to create affinities that will target them to specified cell types or structures. A number of receptors and ligands have been implicated in homing, diapedesis and activation of lymphocytes and metastatic cells in the CNS, including Lselectin (Huang et al, 1991), CD11a (LFA-1), ICAM-1 (Greenwood et al, 1995), CD44, hyaluronate (Aho et al, 1994), VCAM-1 and $\alpha 4$ integrin (Weller et al, 1996; Engelhardt et al, 1995). Myelin protein P2 and myelin oligodendrocyte glycoprotein are thought to be the lymphocyte homing targets in the aforementioned EAN (Kramer et al, 1995) and EAE (Linnington et al, 1993) models. Bombesin, a neuropeptide growth factor, is a known chemoattractant for monocytes and small cell lung carcinoma cells that is theorized to play a role in the development of brain metastases, and thus potential exists for use of its receptor (Ruff et al, 1985). Tumor-specific T cell receptors (TCR), specifically those recognizing the MART-1 melanoma antigen, have been cloned and expressed in T-cell lines to direct activity against melanoma cells (Cole et al, 1995). Antigen binding regions from antibodies have also been expressed on lymphocytes and used to target them to tumor cells (Weijtens et al, 1995). scFv fragment from MAb have been placed into TCR (Gross et al, 1989), and T cells transduced with an anti-folate binding protein scFv-TCR chimera expression cassette have been used to treat metastatic ovarian tumors in a murine model (Hwu et al, 1995). Many of the antigens, receptors and ligands listed in previous sections are potential targets for directing engineered carrier cells to gliomas and other CNS tumors. This strategy may be complicated by the likelihood that not a single receptor, but specific combinations of receptors and activated signaling pathways are involved in lymphocyte trafficking.

\section{Transcription and replication targeting}

In the case of a broadly disseminated vector or carrier cell, selective activation of transcription and/or replication can provide a means of limiting non-target tissue exposure to vector or transgene product. Many viruses intrinsically prefer to function and propagate in mitotic cells, such as tumor cells, which provides some native targeting. This differential towards tumors can be enhanced by deleting genes which are critical for replication in non-dividing cells or modifying transcriptional regulation through selective promoters. Targeting through promoter sequences has been founded in restricting therapeutic transgene expression to target tissue. A broad range of useful promoter and enhancer sequences have thus far been characterized, including those whose function is dependent on cell type, cell cycle status and external stimuli. These allow for great diversity and specificity in tailoring a vector to its intended use.

Most currently used viral vectors preferentially replicate, activate transcription and/or integrate in rapidly dividing cells. This creates marked differential in the CNS where most normal glia and neurons are post-mitotic. In many viruses the selectivity for dividing cells can be enhanced by relatively simple methods. HSV-1, for example, is made nearly replication-conditional to cell division and has demonstrated selective toxicity to tumors, with the disruption of ribonucleotide reductase (Goldstein et al, 1988), ICP-34.5 (Martuza et al, 1991; Kesari et al, 1995; McKie, 1996) or thymidine kinase (Martuza et al, 1991). A separate, but related method of replication targeting has recently been developed, in which E1B deficient replicate with approximately 100 times greater efficiency in tumor cell lines with a functionally inactive p53 protein compared to p53 positive cells (Bischoff et al, 1996). The basis for this phenomonen lies in the normal function of E1B in allowing viral replication through binding and inactivation of p53. Reports of p53 deficiency in up to $30 \%$ of GBM indicates the potential for this methodology (Levine et al, 1991).

In the past, a large number of tumor or tissue selective promoters have been isolated and used to target transgene activation (Table 2). Difficulty has arisen when some regulatory sequences, the JC virus promoter for example (Paulus et al, 1996), appear to have lost tissue specificity when placed in viral constructs. This effect is likely the result of transcriptional override by strong native promoter 
Table 2 Promoter sequences used to target transcription to tumor cells

\begin{tabular}{|c|c|c|}
\hline Promoter & Targeted tumor type & Reference \\
\hline Alpha-fetoprotein (AFP) & Hepatoma & Arbuthnot et al, 1995 \\
\hline Carcinoembryonic antigen (CEA) & Pancrease, lung, breast, colon & $\begin{array}{l}\text { DiMaio et al, } 1994 \\
\text { Osaki et al, } 1994\end{array}$ \\
\hline Glial fibrillary acidic protein (GFAP) & Glioma & Besnard et al, 1991 \\
\hline JC virus immediate early promoter & Glioma & Henson et al, 1994 \\
\hline Myelin basic protein (MBP) & Glioma & Shimizu et al, 1994 \\
\hline Mouse mammary tumor virus & Breast & Arteaga and Holt, 1996 \\
\hline MUC1 & Breast & Chen et al, 1995 \\
\hline Osteocalcin & Osteosarcoma & Ko et al, 1996 \\
\hline Prostate-specific antigen & Prostate & $\begin{array}{l}\text { Pang et al, } 1996 \\
\text { Lee et al, } 1996\end{array}$ \\
\hline Surfactant protein A & Non-small cell lung cancer & Smith et al, 1994 \\
\hline Tyrosinase & Melanoma & Vile et al, 1994 \\
\hline Tyrosinase-related protein & Melanoma & Vile and Holt, 1993 \\
\hline
\end{tabular}

sequences found in many viruses. Attempts are being made to delete or truncate suspect sequences (Ferrari et al, 1995; Vile et al, 1995).

With respect to gliomas, JC virus, glial fibrillary acidic protein (GFAP) and myelin basic protein (MBP) glial selective promoter elements have been characterized and used to drive targeted transgene expression. The JC virus promoter, which produces the glial tropism of the JC virus type that causes progressive multifocal leukoencephalopathy, is based on a glial promoter conserved guanine-rich GA box that binds the Sp1 transcription factor $(\mathrm{MH}-$ 1 strain) (Hensen, 1994) and a TATA box flanking region that binds the glial cell protein Tst-1 (Mad-1 strain) (Krebs et al, 1994). This promoter has produced 30-fold higher transcription in glial compared to non-glial tumor lines (Hensen, 1994). When placed in a retroviral (Paulus et al, 1996) and HSV-1 amplicon (Pechan et al, 1996) vectors, however, extinction of this selectivity has been observed. GFAP is an intermediate-filament protein expressed selectively in reactive astrocytes and is used as a pathologic marker of astrocytic malignancies. The GFAP promoter (gfa2) has been demonstrated to elicit astrocyte-specific marker gene expression in culture and in vivo (Besnard et al, 1991; Brenner et al, 1994). HSV thymidine kinase (HSV-TK) driven by the MBP promoter and delivered by a retroviral vector has produced complete remissions in murine glioma models in conjunction with ganciclovir (Shimizu, 1994). Enhancer elements have also been found within the first and second introns of the nestin, an embryonal filament protein, which direct transcription to mitotic muscle and neural precursor cells (Zimmerman et al, 1994). The serotonin 2 receptor (Ding et al, 1993) and myelin proteolipid protein (Miyao et al, 1993) promoters are also selectively activated in glial cells. Use of promoter elements from the glioma associated antigens mentioned above may also be possible. The promoter region from tenascin, for example, has been characterized (Gherzi et al, 1995).
The potential for using general neoplasia and cell cycle-related promoters also exists. Promoter sequences have been characterized for VEGF (Tischer et al, 1991; Levy et al, 1995) (expression is increased 20-50 times in GBM compared to low-grade gliomas (Weindel et al, 1994)), proliferating cell nuclear antigen (PCNA) (Matsuoka et al, 1993) (expression correlates with aggressiveness in GBM (Schiffer et al, 1997)), basic fibroblast growth factor (bFGF) (Myers et al, 1995) (expression correlates with malignancy in gliomas (Takahashi et al, 1992)), transforming growth factor alpha (TGF $\alpha$ ) (Shin et al, 1995) and C-myc (Kumagai et al, 1995). The grp78 (glucose-related protein) is induced by hypoxia, which is common in tumor tissue, and the promoter has been isolated and used to target transgene expression in a fibrosarcoma model (Gazit et al, 1995).

Transcriptional targeting of tumor vasculature could have the same potential benefits discussed with regards to receptor targeting, namely vascular deprivation and secondary infection of the associated tumor. Multiple vascular or neovasculature related promoters have also been characterized and utilized in therapeutic models. Ozaki et al, used the von Willebrand factor promoter to drive HSV-TK expression in human umbilical vein endothelial cells (HUVEC) using a retroviral vector (Ozaki et al, 1996). The ELAM and ICAM promoters are radiation inducible, ELAM selectively so within endothelial cells (Hallahan et al, 1996). Since neovascular endothelial cells also proliferate rapidly, some of the aforementioned cell cycle related promoters could target transcription to tumor neovasculature as well as tumor.

Various means further exist for activating genes in a temporally or spatially circumscribed manner. The most publicized of these are the radiation or oxidation state-inducible promoters such as those of EGR-1 (early growth response-1) (Datta et al, 1992) and tPA (tissue-type plasminogen activator) (Boothman et al, 1994). In addition to the ELAM and ICAM regulatory sequences discussed previously, 
the IEX-1 (Kondratyev et al, 1996), c-jun (Sherman et al, 1990), Nfk $\beta$ (Brach et al, 1991), IL-1 (Ishihara et al, 1993), EGFR (Peter et al, 1993) and TNFa (Hallahan et al, 1989) genes also appear to be induced by radiation. Radiation inducible promoters have particular potential, since radiation plays a significant role in the treatment of most CNS malignancies and modern techniques allow precise delivery of radiation to the chosen target volume. Furthermore, radiation may increase the transduction efficiency of many vectors (Stevens et al, 1996), and acts synergistically with a number of common transgene systems. The EGR promoter has been used to regulate TNFa, as well as HSV-TK which activates the prodrugs ganciclovir, acyclovir and BVdU. Both systems sensitize cells to radiation in addition to having intrinsic toxicity (Kim et al, 1994, 1995; eischelbaum et al, 1994). The TNFa system has improved tumor growth delays and produced cures in experimental glioma models in conjunction with radiation (Hallahan et al, 1995). Promoter systems have also been designed which are regulated by levels of systemically administered pharmaceuticals such as tetracycline ((positive (Gossen et al, 1995) and negative (Gossen and Bujard, 1992) regulation)), estradiol (Braselmann et al, 1993), estrogen analogue (Whelan et al, 1996), progesterone analogues (Wang et al, 1994) and corticosteroid (Lu and Federoff, 1995). These promoter cassettes have also been combined with tissue selective promoters to create systems that are dually regulated to activate transcription under control of the pharmaceutical only in the target tissue (Fishman et al, 1994).

Promoters elements can be used not only to target transgene activation, but potentially selective in situ propagation of viral vector. Recently the possibility of controlling viral replication through regulation of replication-essential genes with these promoters has been described. Pechan et al, designed a system designated 'piggy back' in which an HSV-1 amplicon and recombinant virus are interdependent on each other for replication, as the amplicon carries the essential intermediateearly gene IE3 which has been deleted from the virus (Pechan et al, 1996). The construct was created with the intent of controlling IE3 expression, thus replication, through a regulatable promoter. In this system, selectivity of promoter sequences was reduced, presumably because of promiscuous HSV-1 enhancer sequences retained in amplicon. The JC promoter was utilized in the initial publication, and we have since placed EGR1 and IEX-1 into amplicons (Spear et al, 1997). This type of system also provides a possible solution to some of the primary difficulties with carrier cells. In this case controlled or targeted activation of viral reproduction or transgene expression would be extraordinarily useful in limiting host cell toxicity before sequestration in the tumor, thus maximizing tumor exposure and minimizing systemic exposure to vector. The basis for a similar system has been created for adenovirus, in which case the E1A gene is deleted from the viral genome and carried in a separate plasmid (Goldsmith et al, 1994). Lymphocyte activation dependent promoters could also be used, such that TILs or other carrier lymphocytes contacting target antigens in a stimulatory tumor microenvironment would simultaneously activate viral production. Candidate regulatory sequences include those of the IL-2, IL-2 receptor, TNFa and interferon gamma (IFNg) genes (Yamada et al, 1987; Vitolo et al, 1992; Camp et al, 1996; Wang et al, 1995; Ioannides et al, 1992).

\section{Conclusion}

Each of the advances discussed in this review has moved the field closer to the goal of a disseminated tumor-selective vector capable of significantly improving the overall therapeutic ratio towards high grade gliomas and other CNS malignancies. Selective delivery of vector to the tumor or sites at risk for involvement increases exposure of malignant cells and decreases exposure of normal cells. Receptor targeting methodologies increase transduction or transfection of tumor and tumor associated cells, frequently while decreasing gene delivery to non-target cells. Targeted carrier cells have significant potential for selective delivery of viral vectors to disseminated tumor sites, including those that may not be accessible by direct or hematogenous delivery of naked vector. Specific promoter sequences have demonstrated ability to preferentially activate toxic transgene transcription in tumor tissues as opposed to normal tissues, and they have further potential to do the same for viral replication. Many of these targeting strategies may be used simultaneously in the same vector in order to further maximize toxicity to the tumor while minimizing toxicity to normal tissues. Similarly, a realistic ultimate objective is not the use of a single gene therapy vector alone with curative intent, but the inclusion of one or several vectors in combined modality therapy with complementary conventional therapies to obtain cures that we now narrowly miss, lengthen expected survival or improve quality of life, as previous incremental advances in conventional therapies have done. 


\section{References}

Aboody-Guterman K, Seena-Esteves M, Herrlinger U, Synder EY, Breakfield XO (1996). Visualization of brain tumor growth and neural cell migration in vivo using retroviral vectors expressing GFP. Soc Neurosci 22: 949.

Aho R, Jakanen S, Kalimo H (1994). CD44-hyaluronate interaction mediates in vitro lymphocyte binding to the white matter of the central nervous system. $J$ Neuropath 53: 295-302.

Albritton LM, Tseng L, Scadden D, Cunningham JM (1995). A putative murine ecotropic retrovirus receptor gene encodes a multiple membrane-spanning protein and confers susceptibility to virus infection. Cell 57: 659-666.

Arbuthnot P, Bralet MP, Thamassin H, Danan JL, Brechot C, Ferry N (1995). Hepatoma cell-specific expression of a retrovirally transferred gene is achieved by alphfetoprotein but no insulinlike growth factor II regulatory sequences. Hepatology 22: 1788-1796.

Arteaga CL, Holt JT (1996). Tissue-targeted antisense cfos retroviral vector inhibits established breast cancer xenografts in nude mice. Cancer Res 56: 1098-1103.

Bartus RT, Elliott PJ, Dean RL, Hayward NJ, Nagle TL, Huff MR, Snodgrass PA, Blunt DG (1996). Controlled modulation of BBB permeability using the bradykinin agonist, RMP-7. Exp Neurol 142: 14-28.

Ben-Shacher D, Yehuda S, Finberg JPM, Spanier I, Youdim MBH (1988). Selective alteration of the blood-brain barrier and insulin transport in irondeficient rats. I Neurochem 50: $1434-1437$.

Berens ME, Rutka JT, Rosenblum ML (1990). Brain tumor epidemiology, growth, and invasion. Neurosurg Clin $N$ Am 1: 1-18.

Bergström M, Collins VP, Ehrin E, Ericson K, Eriksson L, Greitz T, Halldin C, Von Holst H, Langström B, Lilj A, Lundquist H, Nagren K (1983). Discrepancies in brain tumor extent as shown by computed tomography and positron emission tomography using $\left[{ }^{68} \mathrm{Ga}\right]$ EDTA, $\left.{ }^{[11} \mathrm{C}\right]$ glucose, and $\left[{ }^{11} \mathrm{C}\right]$ methionine. J Comput Assist Tomogr 7: $1062-1066$.

Besnard F, Brenner M, Nakatani Y, Chao R, Purohit HJ, Freese E (1991). Multiple interacting sites regulate astrocyte-specific transcription of the human gene for glial fibrillary acidic protein. $J$ Biol Chem 266: $18877-18883$.

Bigner DD, Brown M, Coleman RE, Friedman AH, Friedman HS, McLendon RE, Signer SH, Zhao XG, Wikstrand CJ, Pegram CN et al. (1995). Phase I studies of treatment of malignant gliomas and neoplastic meningitis with ${ }^{131}$ I-radiolabeled monoclonal antibodies anti-tenascin 81C6 and anti-chondroitin proteoglycan sulfate Mel-14F(ab')2 - a preliminary report. J Neurooncol 24: 109-122.

Bischoff JR, Kirn DH, Williams A, Heise C, Horn S, Muna M, Ng L, Nye JA, Sampson-Johannes A, Fattaey A, McCormick F (1996). An adenovirus mutant that replicates selectively in p53-deficient human tumor cells. Science 274: $373-376$.

Boothman DA, Lee IW, Sahijdak WM (1994). Isolation of an x-ray-responsive element in the promoter region of tissue-type plasminogen activator: potential uses of $\mathrm{x}$ ray-responsible elements for gene therapy. Rad Res 138: $\mathrm{S} 68-71$
Boucher Y, Leunig M, Jain RK (1996). Tumor angiogenesis and interstitial hypertension. Cancer Res 56: $4264-4266$

Brach MA, Hass R, Sherman ML, Gunji H, Weichselbaum R, Kufe D (1991). Ionizing radiation induces expression and binding activity of the nuclear factor kappa b. J Clin Invest 88: 691-695.

Braselmann S, Graninger P, Busslinger M (1993). A selective transcriptional induction system for mammalian cells based on Ga14-estrogen receptor fusion proteins. Proc Natl Acad Sci 90: 1657-1661.

Brenner M, Kisseberth WC, Su Y, Besnard F, Messing A (1994). GFAP promoter directs astrocyte-specific expression in transgenic mice. J Neurosci 14: 10301037.

Camp BJ, Dyhrman ST, Memoli VA, Mott LA, Barth RJ (1996). In situ cytokine production by breast cancer tumor-infiltrating lymphocytes. Annals of Surgical Oncology 3: 176-184.

Chen L, Chen D, Manome Y, Dong Y, Fine HA, Kufe DW (1995). Breast cancer selective gene expression and therapy mediated by recombinant adenoviruses containing the DF3/MUC1 promoter. J Clin Invest 96: $2775-2782$.

Cheng PW (1996). Receptor Ligand-facilitated gene transfer: enhancement of liposome-mediated gene transfer and expression by transferrin. Hum Gene Ther 7: 275-282.

Chiocca EA, Andersen J, Takamiya Y, Martuza R, Breakefield XO (1994). Virus-mediated genetic treatment of rodent gliomas. In Gene Therapeutics. Wolf JA (ed.). Birkhauser: Boston,pp. 245-262.

Chu TH, Marinez I, Sheay WC, Dornberg R (1994). Cell targeting with retroviral vector particles containing antibody-envelope fusion proteins. Gene Therapy 1: $292-299$.

Cole DJ, Weil DP, Shilyanski J, Custer M, Kawakami Y, Rosenberg SA (1995). Characterization of the functional specificity of a cloned T-cell receptor heterodimer recognizing the MART-1 melanoma antigen. Cancer Res 55: 748-752.

Cosset FL, Morling FJ, Takeuchi Y, Weiss RA, Collins MK, Russell SJ (1995). Retroviral retargeting by envelopes expressing an $\mathrm{N}$-terminal binding domain. J Virol 69: 6314-6322.

Christiano R, Roth J (1996). Epidermal growth factor mediated DNA delivery into lung cancer cells via the epidermal growth factor receptor. Cancer Gene Ther 3: $4-10$

Culver KW, Ram Z, Walbridge S, Ishii H, Oldfield EH, Blaese RM (1992). In vivo gene transfer with retroviral vector-producer cells for treatment of experimental brain tumors. Science 256: 1550-1552.

Datta R, Rubin E, Suchatme V, Qureshi S, Halahan D, Weichselbaum RR, Kufe DW (1992). Ionizing radiation activates transcription of the EGR1 gene via CArG elements. Proc Natl Acad Sci USA 89: $10149-10153$

DiMaio JM, Clary BM, Via DF Coveney E, Pappas TN, Lyerly HK (1994). Directed enzyme pro-drug gene therapy for pancreatic cancer in vivo. Surgery 116: $205-213$ 
Ding D, Toth M, Zhou Y, Parks C, Hoffman BJ, Shenk T (1993). Glial cell specific expression of the serotonin 2 receptor gene: selective reactivation of a repressed promoter. Brain Res Mol Brain Res 20: 181-191.

Doran SE, Dan Ren X, Betz AL, Pagel MA, Neuwelt EA, Roessler BJ, Davidson BL (1995). Gene expression from recombinant viral vectors in the CNS following blood-brain-barrier disruption. Neurosurgery 36: 965970.

Dore-Duffy P, Balabanov R, Washington R, Swanborg RH (1994). Transforming growth factor beta 1 inhibits cytokine-induced CNS endothelial cell activation. Mol \& Chem Neuropath 22: 161-175.

Elliott PJ, Hayward NJ, Huff MR, Nagle TL, Black KL, Bartus RT (1996). Unlocking the blood-brain barrier: a role for RMP-7 in brain tumor therapy. Exp Neurol 141: $214-224$

Emanuel N, Kedar E, Bolotin EM, Smorodinsky NI, Barenholz Y (1996). Targeted delivery of duxorubicin via sterically stabilized immunoliposomes: pharmacokinetics and biodistribution in tumor-bearing mice. Pharm Res 13: 861-868.

Engelhardt B, Conley F, Kilshaw P, Butcher EC (1995). Lymphocytes infiltrating the CNS during inflammation display a distinctive phenotype and bind to VCAM-1 but not MAdCAM-1. Int Immunol 7: 481-491.

Ferrari G, Salvatori G, Rossi C, Cossu G, Mavilio F (1995). A retroviral vector containing a musclespecific enhancer drives gene expression only in differentiated muscle fibers. Hum Gene Ther 6: $733-742$

Fisher B, Packard BS, Read EJ, Carrasquillo JA, Carter CS, Topalian SL, Yang JC, Yolles P, Larson SM, Rosenberg SA (1989). Tumor localization of adoptively transferred indium-111 labeled tumor infiltrating lymphocytes in patients with metastatic melanoma. J Clin Oncol 7: 250-261.

Fishman GI, Kaplan ML, Buttrick PM (1994). Tetracyclin-regulated cardiac gene expression in vivo. $J$ Clin Invest 93: 1864-1868.

Fishman JB, Rubin JB, Handrahan JV, Connor JR, Fine RE (1987). Receptor-mediated transcytosis of transferrin across the blood-brain barrier. J Neurosci Res 19: $299-304$.

Frieden PM (1993a). Receptor-mediated transport of peptides and proteins across the blood-brain barrier. The Blood-Brain Barrier. WM Pardridge (ed). Raven Press, Ltd.: New York,pp. 229-247.

Frieden PM, Walus LR, Musso GF, Taylor MA, Malfroy B, Starzyk RM (1991). Anti-transferrin receptor antibody and antibody-drug conjugates cross the blood-brain barrier. Proc Natl Acad Sci USA 88: $4771-4775$.

Frieden PM, Walus LR, Watson P, Doctrow SR, Kozarich JW, Backman C, Bergman H, Hoffer B, Bloom F, Granhom AC (1993b). Blood-brain barrier penetration and in vivo activity of an NGF conjugate. Science, 259: $373-377$.

Gao L, Wagner E, Cotten M, Agarwal S, Harris C, Romer M, Miller L, Hu PC, Curiel D (1993). Direct in vivo gene transfer to airway epithelium employing adenovirus-polylysine-DNA complexes. Hum Gene Ther 4: $17-24$.
Gazit G, Kane SE, Nichols P, Lee ES (1995). Use of the stress-inducible grp78/BiP promoter in targeting high level gene expression in fibrosarcoma in vivo. Cancer Res 55: 1660-1663.

Gherzi R, Carnemolla B, Siri A, Ponassi M, Balza E, Zardi L (1995). Human tenascin gene. Structure of the 5 '-region, identification, and characterization of the transcription regulatory sequences. $J$ Biol Chem 270: $3429-3434$.

Gladson CL, Cheresh DA (1991). Glioblastoma expression of vitronectin and the alpha $\mathrm{v}$ beta 3 integrin. Adhesion mechanism for transformed glial cells. $J$ Clin Invest 88: 1924-1932.

Gladson CL, Wilcox JN, Sanders L, Gillespie GY, Cheresh DA (1995). Cerebral microenvironment influences expression of the vitronectin gene in astrocytic tumors. J Cell Science 108: 947-956.

Goldsmith KT, Curiel DT, Engler JA, Garver RI (1994). Trans complementation of an E1A-deleted adenovirus with codelivered E1A sequences to make recombinant adenoviral producer cells. Hum Gene Ther 5: 13411348.

Goldstein DJ, Veller SK (1988). Herpes simplex virus type 1-induced ribonucleotide reductase activity is dispensable for virus growth and DNA synthesis: isolation and characterization of an ICP6 lacZ insertion mutant. J Virol 62: 196-205.

Gossen M, Bujard H (1992). Tight control of gene expression in mammalian cells by tetracycline-responsive promoters. Proc Natl. Acad Sci 89: 5547-5551.

Gossen M, Freundlieb S, Bender G, Muller G, Hillen W, Bujanrd H (1995). Transcriptional activation by tetracyclines in mammalian cells. Science 268: 1766-1769.

Gottschalk S, Cristiano R, Smith L, Wood SL (1994). Folate receptor-mediated DNA delivery and ex-pression in vitro. Gene Ther 1: 185-191.

Gray KD, Roth MJ (1993). Mutational analysis of the envelope gene of Moloney murine leukemia virus. $J$ Virol 67: 3489-3496.

Greenwood J, Wang Y, Calder VL (1995). Lymphocyte adhesion and transendothelial migration in the central nervous system: the role of LFA-1, ICAM-1, VLA-4 and VCAM-1. Immunol 86, 408-415.

Griffith KD, Read EJ, Carrasquillo JA, Carter CS, Yang JC, Fisher B, Aebersold P, Packard BS, Yu MY, Rosenberg SA (1989). In vivo distribution of adoptively transferred indium-111-labeled tumor infiltrating lymphocytes and peripheral blood lymphocytes in patients with metastatic melanoma. J Natl Cancer Inst 81: $1709-1717$.

Gross G, Waks T, Eshar Z (1989). Expression of immunoglobulin T-cell receptor chimeric molecules as functional receptors with antibody-type specificity. Proc Natl Acad Sci USA 86: 10024-10028.

Gutin PH, Prados MD, Phillips TL, Wara WM, Larson DA, Leibel SA, Sneed PK, Levin VA, Weaver KA, Silver P et al (1991). External irradiation followed by an intersittial high activity iodine-125 implant 'boost' in the initial treatment of malignant gliomas: NCOG study 6G-82-2. Int J Radiat Oncol Biol Phys 21: $601-$ 606. 
Hallahan DE, Kataoka Y, Kuchibhotla J, Virudachalam S, Weischelbaum R (1996). Tissue specific promoters improve the localization of radiation-inducible gene expression. Int J Radiat Oncol Biol Phys 36: (Suppl), 226 (abstr 136).

Hallahan DE, Mauceri HJ, Seung LP, Dunphy EJ, Wayne JD, Hanna NN, Toledano A, Helman S, Kufe DW, Weischelbaum RR (1995). Spatial and temporal control of gene therapy using ionizing radiation. Nat Med 8: $786-791$.

Hallahan DE, Spriggs DR, Beckett MA, Kufe DW (1989). Increased tumor necrosis factor alpha mRNA after cellular exposure to ionizing radiation. Proc Natl Acad Sci USA 86: 10104-10107.

Han X, Kasahara N, Kan YW (1995). Ligand-directed retroviral targeting of human breast cancer cells. Proc Natl Acad Sci 92: 9747-9751.

Hatva E, Kaipainen A, Mentula P, Jaaskelainen J, Paetau A, Haltia M, Alitalo K (1995). Expression of endothelial cell-specific receptor tyrosine kinases growth factors in human brain tumors. Am $J$ Path 146: $368-378$.

Henson JW (1994). Regulation of the glial specific JC virus early promoter by the transcription factor $\mathrm{Sp} 1 . J$ Biologic Chem 269: 1046-1050.

Higuchi M, Ohnishi T, Arita N, Hiraga S, Hayakawa T (1993). Expression of tenascin in human gliomas: its relation to histological malignancy, tumor dedifferentiation and angiogenesis. Acta Neuropathol 85: $481-484$.

Huang K, Geoffroy JS, Singer MS, Rosen S (1991). A lymphocyte homing receptor (L-selectin) mediates the in vitro attachment of lymphocytes to myelinated tracts to the central nervous system. J Clin Invest 88: $1778-1783$.

Hurford RK, Dranoff G, Mulligan RC, Tepper RI (1995). Gene Therapy of metastatic cancer by in vivo retroviral gene targeting. Nat Genetics 10: 430-435.

Huwyler J, Wu D, Pardridge WM (1996). Brain drug delivery of small molecules using immunoliposomes. Proc Natl Acad Sci 93: 14164-14169.

Hwu P, Rosenberg SA (1997). Gene therapy of cancer. In Cancer: principles and practice of oncology. Fifth edition. DeVita VT, Hellman S and Rosenberg SA (eds).Lippincott-Raven Publishers: Philadelphia,pp. $3005-3022$

Hwu P, Yang JC, Cowher R, Treisman J, Shafer GE, Eshar Z, Rosenberg SA (1995). In vivo antitumor activity of T-cells redirected with chimeric antibody/T-cell receptor genes. Cancer Res 55: 3369-3373.

Hwu P, Yannelli J, Kriegler M, Anderson WF, Perez C, Chiang Y, Schwarz S, Cowherd R, Delgado C, Mule Jet al (1993). Functional and molecular characterization of TIL transduced with TNFa cDNA for the gene therapy of cancer in man. J Immunol 150: $4104-4115$

Inamura T, Black KL (1994). Bradykinin selectively opens blood-tumor barrier in experimental brain tumors. J Cereb Blood Flow Metab 14: 862-870.

Inoue $M$, Plautz G, Shu S (1996). Treatment of intracranial tumors by systemic transfer of superantigen-activated tumor-draining lymph node $\mathrm{T}$ cells. Cancer Res 56: 4702-4708. oannides CG, Fisk B, Tomasovic B, Pandita R, Aggarwal BB, Freedman RS (1992). Induction of interleukin-2 receptor by tumor necrosis factor alpha on cultured ovarian tumor-associated lymphocytes. Cancer Immunol Immunother 35: 83-91.

Ishihara H, Tsuneoka K, Dimchev AB, Shikita M (1993). Induction of the expression of the interleukin-1 beta gene in mouse spleen by ionizing radiation. Radiat Res 133: $321-326$.

Ito $\mathrm{T}$, Recht L, Salimi A, Brill AB, Raso V, Griffin T (1991). Delivery of antitransferrin receptor MABS into human glioma xenografts: autoradiographic studies (abstr.). Proc Annu Meet Am Assoc Cancer Res 32: A1608.

Ikoh K, Tilden AB, Balch CM (1986). Interleukin 2 activation of cytotoxic T-lymphocytes infiltrating into human metastatic melanomas. Cancer Res 46: 30113017.

Jaworski DM, Kelly GM, Piepmeier JM, Hockfield S (1996). BEHAB (Brain Enriched Hyaluronan Binding) is expressed in surgical samples of glioma and in intracranial grafts of invasive glioma cell lines. Cancer Res 56: $2293-2298$.

Jefferies WA, Brandon MR, Hunt SV, Williams AF, Gatter KC, Mason DY (1984). Transferrin receptor on endothelium of brain capillaries. Nature, 312: 162163

Kasahara NK, Dozy AM, Kan YW (1994). Tissue specific targeting of retroviral vectors through ligand-receptor interactions. Science 266: $1373-1375$.

Kesari S, Randazzo BP, Valyi-Nagy T et al (1995). Therapy of experimental human brain tumors using a neuroattenuated herpes simplex virus mutant. Lab Invest 73: $636-648$.

Kim JH, Kim SH, Kolzsvary BS, Brown SL, Kim OB, Freytag SO (1995). Selective enhancement of radiation response of herpes simplex virus thymidine kinase transduced 9L gliosarcoma cell in vitro and in vivo by antiviral agents. Int J Radiat Oncol Biol Phys 33: $861-868$.

Kim JH, Kim SH, Brown SL, Freytag SO (1994). Selective enhancement by an antiviral agent of the radiation-induced cell killing of human glioma cells transduced with HSVtk gene. Cancer Res 54: 60536056.

Ko SC, Cheon J, Kao C, Gotoh A, Shirakawa T, Sikes RA, Karsenty G, Chung LWK (1996). Osteocalcin promoter-based toxic gene therapy for the treatment of osteosarcoma in experimental models. Cancer Res 56: $4614-4619$.

Kondratyev AD, Chung KN, Jung MO (1996). Identification and characterization of a radiation-inducible glycosylated human early-response gene. Cancer Res 56: $1498-1502$.

Kramer R, Zhang Y, Gehrmann J, Gold R, Thoenen H, Wekerle H (1995). Gene transfer through the blood nerve barrier: NGF-engineered neuritogenic T lymphocytes attenuate experimental autimmune neuritis. Nat Med 1: 1162-1166. 
Kramm CM, Rainov NG, Sena-Esteves M, Barnett FH, Chase M, Herllinger U, Pechan P, Chiocca EA, Breakefield XO (1996). Long-term survival in a rodent model of disseminated brain tumors by combined intrathecal delivery of herpes vectors and ganciclovir treatment. Hum Gene Ther 7: 1989-1994.

Kramm CM, Sena-Esteves M, Barnett FH, Rainov NG, Schuback DE, Yu JS, Pechan PA, Paulus W, Chiocca EA, Breakefield XO (1995). Gene therapy for brain tumors. Brain Pathol 5: $345-381$.

Krebs CJ, McAvoy MT, Kumar G (1994). The JC virus minimal core promoter is glial cell specific in vivo. $J$ Virol 69: $2434-2442$.

Kristiansen K, Hagen S, Kollevold T, Torvik A, Holme I, Nesbakken R, Hatlevoll R, Lindgren M, Brun A, Lindgren S, Notter G, Andersen AP, Elgen K (1981). Combined modality therapy of operated astrocytomas grade III and IV: confirmation of the value of postoperative irradiation and lack of potentiation of bleomycin on survival time: a prospective multicenter trial of the Scandinavian Glioblastoma Study Group. Cancer 47: 649-652.

Kumagai T, Tanio Y, Osaki T, Horai T, Kishimoto $\mathrm{T}$ (1995). Gene therapy for small cell lung cancer cells over-expressing myc family oncogenes by tumourspecific expression of the herpes simplex virus thymidine kinase gene. Gene Ther 2: 33-41.

Kuppner MC, Hamou MF, de Tribolet N (1988). Immunohistological and functional analyses of lymphoid infiltrates in human glioblastomas. Cancer Res 48: $6926-6932$.

Kurnick JT, Kradin RL, Blumberg R, Schneeberger EE, Boyle LA (1986). Functional characterization of $\mathrm{T}$ lymphocytes propagated from human lung car-cinomas. Clin Immunol Immunopathol 38: 367-380.

Ladner RC, Guterman SK (1990). PCT patent application W090/02809.

Lafreniere R, Rosenberg SA (1985). Successful immunotherapy of mutine experimental hepatic metastases with lymphokine-activated killer cells and recombinant interleukin-2. Cancer Res 45: 3735-3741.

Lal B, Indurti RR, Couraud PO, Goldstein GW and Laterra J (1994). Endothelial cell implantation and survival within experimental gliomas. Proc Natl Acad Sci 91: 9695-9699.

Laske DW, Ilercil O, Akbasak A, Youle RJ, Oldfield EH (1994). Efficacy of direct intratumoral therapy with targeted protein toxins for solid human gliomas in nude mice. J Neurosurg 80: 520-526.

Lee CH, Liu M, Sie KL, Lee MS (1996). Prostate-specific antigen promoter driven gene therapy targeting DNA polymerase-a and topoisomerase Iia in prostate cancer. Anticancer Res 16: 1805-1812.

Lee Y, Bullard DE, Humphry PA, Colapinto EV, Friedman HS, Zalutsky MR, Coleman RE, Bigner DD (1988). Treatment of intracranial human glioma xenografts with ${ }^{131}$ I-labeled anti-tenascin monoclonal antibody 81C6. Cancer Res 48: 2904-2910.

Levine AJ, Momand J, Finlay CA (1991). The p53 tumour suppressor-gene. Nature 351: 453-456.

Levy AP, Lev NS, Wegner S, Goldberg MA (1955). Transcriptional regulation of the rat vascular endothelial growth factor gene by hypoxia. J Biol Chem 270: $13333-13340$
Linington C, Berger T, Perry L, Weerth S, Hinze-Selch D, Zhang $\mathrm{Y}, \mathrm{Lu} \mathrm{H}$, Lassmann $\mathrm{H}$, Wkerle $\mathrm{H}$ (1993). T cells specific for the myelin oligodendricyte glycoprotein mediate an unusual auto immune inflammatory response in the central nervous system. Eur $J$ Immunol 23: 1364-1372.

Lu B, Federoff HJ (1995). Herpes simplex virus type I amplicon vectors with glucocorticoid-inducible gene expression. Hum Gene Ther 6: 419-428.

Lubbe AS, Bergemann C, Riess H, Schriever F, Reichardt P, Possinger K, Matthias M, Dorken B, Herrmann F, Gurtler R, Hohenberger P, Haas N, Sohr R, Sander B, Lemke AJ, Ohlendorf D, Huhnt W, Huhn D (1996). Clinical experiences with magnetic drug targeting: a phase I study with 4 '-epidoxorubicin in 14 patients with advanced solid tumors. Cancer Res 56: 46864693.

Martin M, Noel D, Valsesia-Wittman S, Brockly F, Etienne-Julan M, Russell S, Cosset FL, Piechaczyk M (1996). Targeted infection of human cells via major histocompatibility complex class I molecules by Moloney murine leukemia virus-derived viruses displaying single-chain antibody fragment-envelope fusion proteins. J Virol 70: 2957-2962.

Martell LA, Agrawal A, Ross DA, Muraszko KM (1993). Efficacy of transferrin receptor-targeted immunotoxins in brain tumor cell lines and pediatric brain tumors. Cancer Res 53: 1348-1353.

Martuza RL, Malick A, Markert JM, Ruffner KL, Coen DM (1991). Experimental therapy of human glioma by means of a genetically engineered virus mutant. Science 252: 854-856.

Matsuoka S, Yamaguchi M, Hiyashi Y, Matsukage A (1993). Nucleotide sequence and promoter-specific effect of a negative regulatory region located upstream of the mouse proliferating cell nuclear antigen gene. Eur J Biochem 218: $173-181$.

McKie EA, MacLean AR, Lewis AD et al (1996). Selective in vitro replication of herpes simplex virus type 1 (HSV-1) ICP34.5 null mutants in primary human CNS tumors- evaluation of potentially effective clinical therapy. Br J Cancer 75: 745-752.

Michael SI, Hong JS, Curiel DT, Engler JA (1995). Addition of a short peptide ligand to the adenovirus fiber protein. Gene Ther 2: 660-668.

Miescher S, Whiteside TL, Moretta L, von Fliedner V (1987). Clonal and frequency analyses of tumorinfiltrating $\mathrm{T}$ lymphocytes from human solid tumors. J Immunol 142: 4004-4011.

Miyao Y, Shimizu K, Moriuchi S, Yamada M, Nakahira K, Nakajima K, Nakao J, Kuriyama S, Tusjii T, Mikoshiba K, Hayakawa T, Ikenaka K (1993). Selective expression of foreign genes in glioma cells: use of the mouse myelin basic protein gene promoter to direct toxic gene expression. J Neurosci Res 36: $472-479$.

Mule JJ, Shu S, Rosenberg SA (1984). Adoptive immunotherapy of established pulmonary metastases with LAK cells and recombinant interleukin-2. Science 225: 1487.

Myers RL, Ray SK, Eldridge R, Chotani MA, Chiu IM (1995). Functional characterization of the brainspecific FGF-1 promoter, FGF-1.B. J Biol Chem 270: 8257 - 8266. 
Negrier S, Philip T, Stoter G, Fossa SD, Janssen S, Iacone A, Cleton FS, Eremin O, Israel L, Jasmin C et al (1989). Interleukin-2 with or without LAK cell in metastatic renal cell carcinoma: A report of a European multicentre study. Eur J Cancer Clin Onco 25: $\mathrm{S} 21-28$.

Nerrouche Y, Negrier S, Bain C, Combaret V, Mercatello A, Coronel B (1995). Clinical application of retroviral gene transfer in oncology: results of a French study with tumor-infiltrating lymphocytes transduced with the gene of resistance to neomycin. J Clin Oncol 13: $410-417$.

Netti PA, Baxter LT, Boucher Y, Skalak R, Jain RK (1995). Time-dependent behavior of intersittial fluid pressure in solid tumors: implications for drug delivery. Cancer Res 55: 5451-5458.

Neuwelt EA, Hill SA (1987). Chemotherapy administered in conjunction with osmotic blood-brain barrier modification in patients with brain metastates. $J$ Neuro-oncol 4: 195-207.

Nilaver G, Muldoon LL, Kroll RA, Pagel MA, Breakefield XO, Davidson BL, Neuwelt EA (1995). Delivery of herpesvirus and adenovirus to nude rat intracerebral tumors following osmotic blood-brain barrier disruption. Proc Natl Acad Sci 92: 9829-9833.

O’Neil KT, Hoess RH (1995). Phage display: protein engineering by directed evolution (review). Cur Opinion Struct Biol 5: 443-449.

Oldfield EH, Ram Z, Culver KW, Blaese RM, DeVroom HL, Anderson WF (1993). Gene therapy for the treatment of brain tumors using intra-tumoral transduction with the thymidine kinase gene and intravenous ganciclovir. Hum Gene Ther 4: 39-69.

Osaki T, Tanio Y, Tachibana I, Hosoe S, Kumagai T, Kawase I, Oikawa S, Kisismoto T (1994). Gene therapy for carcinoembryonic antigen-producing human lung cancer cells by cell-type specific expression of herpes simplex virus thymidine kinase gene. Cancer Res 54: 5258-5261.

Ozaki K, Yoshida T, Ide H, Saito I, Ideda Y, Sugimura T, Terada M (1996). Use of von Willebrand factor promoter to transduce suicidal gene to human endothelial cells, HUVEC. Hum Gene Ther 7: 14831490.

Paine JT, Handa H, Yamasaki T, Yamashita J, Miyatake S (1986). Immunohistochemical analysis of infiltrating lymphocytes in central nervous system tumors. Neurosurg 18: $766-772$.

Pang S, Dannul LJ, Kaboo R, Xie Y, Tso C, Michel K, deKernion JB, Belldegrun AS (1996). Identification of a positive regulatory element responsible for tissuespecific expression of prostate-specific antigen. Cancer Res 57: 495-499.

Papa MZ, Mule JJ, Rosenberg SA (1986). Antitumor efficacy of lymphokine-activated killer cells and recombinant interleukin-2 in vivo: Successful immunotherapy of established pulmonary metastases from weakly immunogenic and nonimmunogenic murine tumors of three distict histological types. Cancer Res 46: $4973-4978$.

Parmley SF, Smith GP (1989). Antibody-selectable filamentous fd phage vectors: Affinity purification of target genes. Gene 73: 305-318.

Pasqualini R, Ruoslahti E (1996). Organ targeting in vivo using phage display peptide libraries. Nature 380: $364-366$.
Paulus W, Baur I, Boyce FM, Breakefield XO, Reeves SA (1996). Self-contained, tetracycline-regulated retroviral vector system for gene delivery to mammalian cells. $J$ Virol 70: $62-67$.

Pechan PA, Fotaki M, Thompson RL, Dunn R, Chase M, Chiocca EA, Breakefield XO (1996). A novel 'piggyback' packaging system for herpes simplex virus amplicon vectors. Hum Gene Ther 7: 2003-2013.

Peter RU, Beetz A, Ried C, Michel G, van Beuningen D, Ruzicka $T$ (1993). Increased expression of the epidermal growth factor receptor in human epidermal keratinocytes after exposure to ionizing radiation. Radiat Res 136: 65-70.

Plate KH, Breier G, Weich HA, Mennel HD, Risau W (1994). Vascular endothelial growth factor and glioma angiogenesis: coordinate induction of VEGF receptors, distribution of VEGF protein and possible in vivo regulatory mechanisms. Int J Cancer 59: 520-529.

Rabinowich H, Cohen R, Bruderman I (1987). Functional analysis of mononuclear cells infiltrating into tumors: lysis of autologous human tumor cells by cultured infiltrating lymphocytes. Cancer Res 47: $173-177$

Rainov NG, Zimmer C, Chase M, Kramm CM, Chiocca EA, Weissleder R, Breakefield XO (1995). Selective uptake of viral and monocrystalline particles delivered intra-arterially to experimental brain neoplasms. Hum Gene Ther 6: 1543-1552.

Rosenberg SA, Aebersold P, Cornetta K, Kasid A, Morgan RA, Moen R, Karson EM, Lotze MT, Yang JC, Topalian SL et al (1990). Gene transfer into humans-immunotherapy of patients with advanced melanoma, using tumor-infiltrating lymphocytes modified by retroviral gene transduction. $N$ Engl $\mathrm{J} \mathrm{Med}$ 323: $570-578$.

Ruff M, Schiffman E, Terranova V, Pert CB (1985). Neuropeptides are chemoattractants for human tumor cells and monocytes: a possible mechanism for metastasis. Clin Immuno and Immunopath 37: $387-$ 396.

Russel SJ, Hawkins RE, Winter G (1995). Retroviral vectors displaying functional antibody fragments. Nucleic Acids Res 21: 1081-1085.

Saris SC, Spiess P, Lieberman DM, Lin S, Walbridge S, Oldfield EH (1992). Treatment of murine primary brain tumors with systemic interleukin-2 and tumorinfiltrating lymphocytes. J Neurosurg 76: 513-519.

Schiffer D, Cavalla P, Dutto A, Borsotti L (1997). Cell proliferation and invasion in malignant gliomas. Anticancer Res 17: 61-69.

Schnierle BS, Groner G (1996a). Retroviral targeted delivery. Gene Ther 3: 1069-1073.

Schnierle BS, Moritz D, Jeschke M, Groner B (1996b). Expression of chimeric envelope proteins in helper cell lines and integration into Moloney murine leukemia virus particles. Gene Therapy 3: $334-342$.

Schoof DD, Gramolini CA, Davidson DL, Massaro AF, Wilson RE, Eberlein TJ (1988). Adoptive immunotherapy of human cancer using low-dose recombinant interleukin-2 and lymphokine-activated killer cells. Cancer Res 48: 5007-5010.

Schwarzenberger P, Spence SE, Gooya JM Michiel D, Curiel DT, Ruscetti FW, Keller JR (1996). Targeted gene transfer to human hematopoietic progenitor cell lines through the c-kit receptor. Blood 87: 472-8. 
Scott JK, Smith GP (1990). Searching for peptide ligands with an epitope library. Science 249: 386-390.

Sherman ML, Datta R, Hallahan DE, Weichselbaum RR, Kufe DW (1990). Ionizing radiation regulates expression of the $c$-jun protooncogene. Proc Natl Acad Sci USA 87: 5663-5666.

Shimizu K (1994). Selective gene therapy of malignant gliomas using brain-specific promoters: its efficacy and basic investigation. Nippon Rinsho (Japanese J Clin Med), 52: $3053-3058$.

Shin TH, Paterson AJ, Kudlow JE (1995). p53 stimulates transcription from the human transforming growth factor alpha promoter: a potential growth-stimulatory role for p53. Mol Cell Bio 15: 4694-4701.

Short MP, Choi B, Lee J, Malick A, Breakefield XO, Martuza RL (1990). Gene delivery to glioma cells in rat brain by grafting of a retrovirus packaging cell line. J Neurosci Res 27: 427-439.

Shu S, Chou T, Rosenberg SA (1987). Generation from tumor-bearing mice of lymphocytes with in vivo therapeutic efficacy. J Immunol 139: 295-304.

Smith MJ, Rousculp MD, Goldsmith KT, Curiel DT, Garver RK (1994). Surfactant protein A-directed toxin gene kills lung cancer cells in vitro. Hum Gene Ther 5: $29-35$.

Snyder EY, Deitcher DL, Walsh C, Arnold-Aldea S, Hartweig EA, Cepko CL (1992). Multipotent neuronal cell lines can engraft and participate in development of mouse cerebellum. Cell 68: 33-51.

omia NV, Zoppe M, Verma IM (1995). Generation of targeted retroviral vectors by using single-chain variable fragment: an approach to in vivo gene delivery. Proc Natl Acad Sci 92: 7570-7574.

Spear MA, Li C, Weissleder R, Putney S, Pechan P, Breakefield XO (1997). Ox26 Monoclonal Antibody Targets HSV-1 Vector to Transferrin Receptor-Bearing Cells. Proc Am Assoc Cancer Res 38: 343(A2302).

Spear MA, Sakamoto KM, Herrlinger U, Pechan PP, Breakfield XO (1997). Function of the EGR-1 promoter in a minimal HSV-1 amplicon vector system. Proc Am Soc Ther Rad Oncol (In press).

Stevens CW, Zeng M, Cerniglia GJ (1996). Ionizing radiation greatly improves gene transfer efficiency in mammalian cells. Hum Gene Ther 7: 1727-1734.

Takahashi JA, Fukumoto M, Igarashi K, Oda Y, Kikuchi H, Hatanaka M (1992). Correlation of basic fibroblast growth factor expression levels with the degree of malignancy and vascularity in human gliomas. $J$ Neurosurg 76: $792-798$.

Tischer E, Mitchell R, Hartman T, Silva M, Gospodarowicz D, Fiddes JC, Abraham JA (1991). The human gene for vascular endothelial growth factor. Multiple protein forms are encoded through alternative exon splicing. J Biol Chem 266: $11947-$ 11954.

Urien S, Pinquier JL, Paquette B, Chaumet-Riffaud P, Kiechel JP, Tillement JP (1987). Effect of the binding of isradipine and darodapine to different plasma proteins and their transfer through the rat bloodbrain barrier: drug binding to lipoproteins does not limit the transfer of drug. J Pharmacol Exp Ther 242: $349-353$

Ventimiglia JB, Wikstrand CJ, Ostrowdki LE, Bourdon MA, Lightner VA, Bigner DD (1992). Tenascin expression in human glioma cell lines and normal tissues. J Neuroimmunol 36: 41-55.
Vile RG, Miller N, Chernajovsky Y, Hart I (1994). Ca comparison of the properties of different retroviral vectors containing the mutine tyrosinase promoter to achieve transcriptionally targeted expression of the HSVtk or IL-2 genes. Gene Ther 1: 307-316.

Vile RG, Diaz RM, Miller N, Mitchell S, Russell SJ (1995). Tissue-specific gene expression form Mo-MLV retroviral vectors with hybrid LTRs containing the murine tyrosinase enhancer/promoter. Virology 214: $307-313$.

Vile RG, Hart IR (1993). In vitro and in vivo targeting of gene expression to melanoma cells. Cancer Res 53: $962-967$.

Vitolo D, Zerbe T, Kanbour A, Dahl C, Herberman RB, Whiteside TL (1992). Expression of mRNA for cytokines in tumor-infiltrating mononuclear cells in ovarian adenocarcinoma and invasive breast cancer. Int $J$ Cancer 51: 573-580.

Wagner E, Zatloukal K, Cotten M, Kirlappos H, Mechtler K, Curiel DT, Birnstiel ML (1992). Coupling of adenovirus to transferrin-polylysine/DNA complexes greatly enhances receptor-mediated gene delivery and expression of transfected genes. Proc Natl Acad Sci 89: $6099-6103$.

Walker MD, Alexander E, Hunt WE, MacCarty CS, Mahaley MS, Mealey J, Norrell HA, Owens G, Ransohoff J, Wilson CB, Gehan EA, Strike TA (1978). Evaluation of BCNU and/or radiotherapy in the treatment of anaplastic gliomas. J Neurosurg 49: $333-343$.

Wang Q, Redovan C, Tubbs R, Olencki T, Klein E, Kudoh S, Finke J, Bukowski RM (1995). Selective cytokine gene expression in renal cell carcinoma tumor cells and tumor-infiltrating lymphocytes. Int $J$ Cancer 61: 780-785.

Wang Y, Tsai SY, O’Malley BW (1994). A regulatory system for use in gene transfer. Proc Natl Acad Sci 91: $8180-8184$.

Weijtens M, Willemsen R, Valerio D, Stam K, Bolhuis R (1995). Functional expression of a single chain Fv/g receptor with renal cell carcinoma specificity in activated human PBL; single chain antibody Fv fragment and FceRI receptor fusion gene expression in cytotoxic T-lymphocyte or peripheral blood lymphocyte using LXSN retro virus vector (abstract). $J$ Mol Med 73: B13.

Weindel K, Moringlane JR, Marme D, Weich HA (1994). Detection and quantification of vascular endothelial growth factor/vascular permeability factor in brain tumor tissue and cyst fluid: the key to angiogenesis?

Weischelbaum RR, Hallahan DE, Becket MA, Hauceri HJ, Lee H, Sukhatme VP, Kufe DW (1994). Gene therapy targeted by radiation preferentially radiosensitizes tumor cells. Cancer Res 54: 4266-4269.

Weller M, Fontana A (1995). The failure of current immunotherapy for malignant glioma. Tumor-derived TGF-B, T-cell apoptosis, and the immune privilege of the brain. Brain Res Rev 21: 128-151.

Weller RO, Engelhardt B, Phillips M (1996). Lymphocyte targeting of the central nervous system: a review of afferent and efferent CNS-immune pathways. Brain Pathology 6: $275-288$.

Whelan J, Miller N (1996). Generation of estrogen receptor mutants with altered ligand specificity for use in establishing regulatable gene expression system. I Steroid Biochem Mol Biol 58: 3-12. 
Wickham TJ, Segal DM, Roelvink PW, Carrion ME, Lizonova A, Lee GM, Kovesdi I (1996). Targeted adenovirus gene transfer to endothelial and smooth muscle cells by using bispecific antibodies. J Virol 70: $6831-6838$

Yamada S, Ruscetti FW, Overton WR, Herberman RB, Birchenall-Sparks MC, Ortaldo JR (1987). Regulation of human large granular lymphocytes and $\mathrm{T}$ cell growth and function by recombinant interleukin 2 . I. Induction of interleukin 2 receptor and promotion of growth of cells with enhanced cytotoxicity. J Leukocyte Biol 41: 505.

Yanase T, Tamura M, Fujita K, Kodama S, Tanaka K (1993). Inhibitory effect of angiogenesis inhibitor TNP470 on tumor growth and metastasis of human cell lines in vitro and in vivo. Cancer Res 53: 2566-2570.

Yoshida S, Tanaka R, Ono M, Takai N, Saito T (1989). Analysis of mixed lymphocyte-tumor culture in patients with malignant brain tumor. J Neurosurg 71: $398-402$.
Yuan F, Dellian M, Fukumura D, Leunig M, Berk DA, Torchilin VP, Jain RK (1995). Vascular permeability in a human tumor xenograft: molecular size dependence and cutoff size. Cancer Res 55: 3752-3756.

Zalutsky MR, Moseley RP, Coakham HB, Coleman RE, Bigner DD (1989). Pharmacokinetics and tumor localization of ${ }^{131}$ I-labeled anti-tenascin monoclonal antibody 81C6 in patients with gliomas and other intracranial malignancies. Cancer Res 49: 2807-2813. Zimmerman L, Parr B, Lendahl U, Cunningham M, McKay R, Gavin B, Mann J, Vassileva G, McMahon A (1994). Independent regulatory elements in the nestin gene direct transgene expression to neural stem cells or muscle precursors. Neuron 12: 11-24.

Zünkeller B, Carson RE, Olson J, Blasberg RG, DeVroom H, Lutz RJ, Saris SC, Wright DC, Kammerer W, Patronas NJ, Dedrick RL, Herscovitch P, Oldfield EH (1996). Quantification and pharmacokinetics of bloodbrain barrier disruption in humans. J Neurosurg 85: $1056-1065$. 